\title{
CrimRxiv
}

\section{Confronting Child Sexual Abuse: Knowledge to Action}

\author{
Anne M. Nurse
}

Published on: Jul 01, 2020

DOI: $10.21428 / \mathrm{cb} 6 \mathrm{ab} 371.9811 \mathrm{dc15}$

License: Creative Commons Attribution 4.0 International License (CC-BY 4.0). 
